\title{
ICC and ASEAN: Weakening or Strengthening National Criminal Justice System?
}

\author{
Chloryne Dewi* \\ DOI: https://doi.org/10.22304/pjih.v6n2.a10
}

Submitted: April 5, 2019 | Accepted: September 28, 2019

\begin{abstract}
The objective of the establishment of the International Criminal Court by the Rome Statute 1998 is to achieve global justice. The spirit to end impunity established the ICC to respond to four previous criminal tribunals that have been criticized as victor's justice and selective justice. The ICC has material jurisdiction on the four most serious crimes: crimes against humanity, genocide, war crimes, and crimes of aggression. These crimes can be committed in any part of the world, including Southeast Asia. The latest case was crimes against humanity that lead to genocide of the Rohingya people in Myanmar, not to mention extra judicial killings as a policy of drugs war and towards journalist in the Philippines. However, none of the case has been brought to justice. In view of that, this study examined challenges and opportunities toward the implementation of Rome Statute 1998 in Southeast Asia. Furthermore, it also observed possible impacts in implementing Rome Statute 1998 in Southeast Asia. The existing national legal instruments related to ICC can support the implementation of Rome Statute 1998 in Southeast Asia and achieve the objective of ICC to end impunity and to reach global justice. Nevertheless, challenges come from the governments of Southeast Asian states. They are reluctant to bring justice and fear that ICC can violate national sovereignty. Interestingly, the Philippines just withdrew itself as a state party to ICC since 2018. Based on the basic principle of complementarity, the ICC is proposed to strengthening national criminal justice of a state. Therefore, the ICC should not be considered as a threat to national sovereignty of a state.
\end{abstract}

Keywords: ASEAN, International Criminal Court, Rome Statute 1998

\section{Mahkamah Pidana Internasional dan Asean: Melemahkan atau Menguatkan Sistem Peradilan Pidana Nasional?}

\begin{abstract}
Abstrak
Tujuan pembentukan Mahkamah Pidana Internasional (International Criminal Court/ICC) melalui Statuta Roma 1998 adalah untuk mencapai keadilan global dengan semangat memerangi dan bahkan menghapuskan impunitas. Mahkamah Pidana Internasional merupakan respon masyarakat internasional terhadap empat pengadilan pidana internasional sebelumnya yang dianggap tidak adil karena lebih memihak pada pemenang perang (victor's justice) dan hanya mengadili orang-orang tertentu (selective justice).
\end{abstract}

PADJADJARAN Journal of Law Volume 6 Number 2 Year 2019 [ISSN 2460-1543] [e-ISSN 2442-9325]

Lecturer of the Faculty of Law Universitas Padjadjaran, Jl. Imam Bonjol No. 21 Bandung 40132 Indonesia, S.H. (the Faculty of Law Universitas Padjadjaran Indonesia), LL.M (the School of Law University of NottinghamUnited Kingdom), email: chloryne.dewi@unpad.ac.id 
Jurisdiksi materil dari ICC terdiri dari empat kejahatan paling serius di dunia yaitu kejahatan terhadap kemanussiaan, genosida, kejahatan perang dan kejahatan agresi. Keempat kejahatan tersebut dapat terjadi di belahan dunia manapun, termasuk Asia Tenggara. Kasus terakhir yang menyita perhatian dunia yaitu tindakan pemerintah Myanmar terhadap kelompok Rohingya yang dapat dikategorikan sebagai kejahatan terhadap kemanusiaan yang juga mengarah pada genosida. Selain itu beberapa kasus pembunuhan sewenangwenang (extra judicial killings) sebagai perang terhadap narkoba termasuk kepada para jurnalis juga masih terjadi di Filipina. Namun hingga saat ini kasus-kasus tersebut belum dapat diselesaikan secara hukum. Oleh karenanya, tulisan ini akan membahas tantangan dan peluang implementasi Statuta Roma 1998 di negara-negara ASEAN. Selain itu, tulisan ini juga mencoba menganalisa dampak yang dapat terjadi bilamana Statuta Roma 1998 diimplementasikan di ASEAN. Riset menunjukan bahwa peraturan perundangan nasional yang telah ada dapat mendukung implementasi Statuta Roma untuk mencapai tujuannya. Namun, sikap pemerintah negara-negara ASEAN diantaranya ketidakmauan untuk menegakkan hukum dalam rangka perlindungan HAM dan kegelisahan ICC akan merongrong kedaulatan negara menjadi tantangan terbesar. Bahkan, Filipina yang telah menjadi negara pihak menarik diri sejak tahun 2018. Prinsip dasar komplementaritas yang dimiliki ICC berupaya untuk menguatkan sistem hukum pidana suatu negara. Sehingga, Statuta Roma tidak perlu dianggap sebagai ancaman kedaulatan negara.

Kata Kunci: ASEAN, Mahkamah Pidana Internasional, Statuta Roma 1998

\section{A. Introduction}

The International Criminal Court (ICC) has three main objectives. First, it is to achieve global justice ${ }^{1}$ by applying its jurisdiction without discrimination. However, since was established by an international agreement, the ICC can only apply its jurisdiction towards state parties to the Rome Statute 1998. In spite of that, the Security Council can act under Chapter VII of the United Nations Charter to refer a case of a non-state party to the ICC based on the Article 13(b) of the Rome Statute 1998. ${ }^{2}$ This article should be treated equally to all nationals based on the second objective of the ICC to end impunity. The ICC intended to end impunity against perpetrators of the most serious crimes of international criminal law. The principle of individual criminal responsibility, which was introduced in Nuremberg Trial $^{3}$, and the principle of commander responsibility, which was brought in the case of Mladic $^{4}$ and Karadzic ${ }^{5}$, also emphasize that there is no excuse to hide from

1 See Louis Moreno Ocampo, "The International Criminal Court: Seeking Global Justice”, Case Western Journal of International Law, Vol. 40, Issue 1, 2008.

2 Article 13 Rome Statute 1998: "The Court may exercise its jurisdiction with respect to a crime referred to in article 5 in accordance with the provisions of this Statute if: ...( b ) A situation in which one or more of such crimes appears to have been committed is referred to the Prosecutor by the Security Council acting under Chapter VII of the Charter of the United Nations"

3 William Schabas, An Introduction to the International Criminal Court, Cambridge: Cambridge University Press, 2001, p. 54

4 Prosecutor $v$ Ratco Mladić (IT-95-5/18). He was accused for his capacity as the Commander of the Main Staff of the army of the Serbian Republic of Bosnia and Herzegovina/Republika Srpska (VRS) pursuant to article 7(3) Statute of ICTY. Furthermore, the prosecutor emphasize that "committed" is not only physical act but also 
responsibility for crimes that has been committed. It is applied equally to everyone, even for a head of state -for instance, the case of President Al Bashir ${ }^{6}$, of Sudan. Finally, yet importantly, the ICC is intended to support national criminal justice mechanism to work more effectively. Based on complementarity principle, the ICC will not intervene if a state is processing (investigating or prosecuting) a case of international crimes within the jurisdiction of ICC. ${ }^{7}$ In other words, the ICC is not a supra national institution. Confidently, the ICC can bring positive development to national criminal justice, particularly to states with high risk of international crimes offences. Hence, the ICC is expected to bring justice, particularly for the victims of crimes against humanity, genocide, war crimes, and crimes of aggression. ${ }^{8}$ As the only international criminal tribunal that has rationae loci all over the world, ICC is intended to halt the critics of victor justice as well as selective justice as experienced by the previous tribunals.

Human rights atrocities occurred indiscriminately, regardless time, place, type of state, wealth, culture, and people. Human rights atrocities are also committed in Southeast Asia. In fact, the international community tends to monitor African and Middle Eastern states instead of other parts of the world. ${ }^{9}$ Serious violations of human rights in Myanmar, Philippines, Thailand, Malaysia, and Indonesia are note less important to be concerned seriously.

States of Southeast Asia have crimes against humanity and war crimes cases. The main cause of the offences usually due to the tendency of repressive government. Issue of unjust treatment to the minority groups also one of the common grounds of atrocities. Admittedly, it leads to insurgency and develop into internal armed conflict. Undeniably, parties in hostility often commit war crimes. The most obvious example is Myanmar under the power of junta; Thailand with Muslim group in south and Burmese refugees; Indonesia with Aceh and Papua Liberation Movement including former province of East Timor; the Philippines with Muslim group of Moro in south; Malaysia with Hindu group and migrant workers as well as Burmese refugees; or Khmer Rouge in Cambodia. In addition, student and civil movements protesting the government is also a common pattern when state using its power which sometimes arbitrary and causing crimes against humanity.

includes participation in a joint criminal enterprise. See Amended Indictment Prosecutor v Ratco Mladić Case No. IT-95-5/18-I. http://www.icty.org/x/cases/mladic/ind/en/mla-ai021010e.pdf

5 Prosecutor v Karadžić (IT-95-5/18-I). Karadzic was indicted based on individual criminal responsibility and superior criminal responsibility for the crimes of genocide, extermination, murder, deportation, inhuman acts, violations article 3 of the laws of war.

6 Situation in Darfur, Sudan the Prosecutor v Omar Hassan Ahmad Al Bashir case no. ICC-02/05-01/09.

7 William Schabas, op.cit., p. 14.

8 Madeline Morris, "Complementarity and its Discontents: States, Victims, and The International Criminal Court" in Dinah Shelton (ed), International Criminal Crimes, Peace and Human Rights, Ardsley: Transnational Publisher, 2000, p. 180.

9 Catherine Gegout, "The International Criminal Court: Limits, Potentials and Conditions for the Promotion of Peace and Justice", Third World Quarterly, Vol. 34 Issue 5, 2013, p. 803. 
The governments act irresponsive in responding the issues, particularly to bring justice due to various reasons. Indonesia established ad hoc tribunal for crimes occurred in East Timor but the perpetrators are still enjoying impunity. Myanmar is quite defensive and resistant in responding the report by United Nations special rapporteur on human rights or some human rights NGOs on human rights situation in Myanmar. They give similar response to the ICC. East Timor and Cambodia respond it enthusiastically by ratifying the Rome Statute 1998 in 2002 and the Philippines in 2011. However, the Philippines withdraw its position on March 17, 2018. ${ }^{10}$ Southeast Asian states are more careful in responding the issue of state sovereignty from the intervention by international institution.

On the other hand, community and human rights defenders in these states are seeking for justice by encouraging the governments to be the parties to the ICC. They believe that the principle of complementarity enables the ICC to play its role to develop criminal justice enforcement at national level. At the same time, the ICC can help to end impunity and bring justice for the victims.

\section{B. The Most Serious Crimes in ASEAN}

Mostly, the states of Southeast Asia are governed by military and monarchy regimes. Abuse of power, corruption, discrimination (towards minority groups), dictatorship, and repressive action against opposition of government are common problems in developing countries. Consequently, it leads to various civil movements against repressive power. The patterns are various, from individual written protest through note or mail to the government, to liberation movement. Some civil movements have brought states into reformation, which leads to the stage of development, in not only economic sector but also democracy and rule of law. ${ }^{11}$

Nevertheless, the process is not always easy. Violence against opposition or even the innocent civilian has been hardly to avoid since government has all power. Armed conflict between ruler and civil liberation movement often occurs. Undeniably, both parties also commit serious violation of human rights and humanitarian law. Nonetheless, both parties are not responsible. Perpetrators enjoy their impunity due to the inexistence of law or government's protection.

\section{Crimes against humanity}

Article 7 of the Rome Statute 1998 emphasizes the element "committed as a part of widespread or systematic attack", "directed against any civilian population", and

10 ICC Press Release, Press Release: 20 March 2018, ICC Statement on The Philippines' notice of withdrawal: State participation in Rome Statute system essential to international rule of law, https://www.icccpi.int/Pages/item.aspx?name=pr1371 on 15 August 2018.

11 Adlon D Morris, "A Retrospective on the Civil Rights Movement: Political and Intellectual Landmark", Annual Review of Sociology, Vol.25, 1999, p.518 see also Hugh Davis Graham, The Civil Rights Era: Origins and Development of National Policy, 1960-1972 , New York: Oxford, 1990,p 125-176 
"with knowledge to attack". Furthermore, Article 7 Paragraph 2 (a) explicates that the attack is "a course of conduct involving the multiple commission of acts... pursuant to or in furtherance of a State or organizational policy to commit such attack". ${ }^{12}$ This article stresses the act of multiple commission of acts'. It means that any act refers to the Paragraph 1 of Article 7 may be committed more than once or more than one act. ${ }^{13}$ In addition, the article also emphasizes 'state or organizational policy' that indicates the act are part of the policy of the authority. ${ }^{14}$

Definitely, the repressive government likely commits those elements of crimes particularly towards anyone who oppose them. The opposition covers opposite not only political parties, but also individuals or civil society disagreeing with government's policy or act. In addition, due to plurality of state's inhabitants, minority groups are often being subject of discrimination and violence of ruler, who is usually from majority group.

Feeling inconvenience with critics and disagreements, in addition to the principle 'government never do wrong', a repressive ruler tends to use power to take any measure to give 'understanding' to opposition. In fact, form of 'understanding' usually acted as a violence action from terror to extrajudicial killing. This is not excluding restriction of rights for its nationals particularly freedom of expression, secret operation towards individuals or groups who are suspected as left-activist or even institutionalizing human rights violations and/or offences by the government into legislations to make it legal.

In February 2018, the preliminary examination on the situation of the Philippines with alleged crimes committed on the context of "war on drugs" campaign since July 1,2016 , was launched. ${ }^{15}$ It is alleged that since July 1,2016 , thousands of people were killed due to allegation of involvement in illegal drug use or dealing. Some of the killings are reportedly occurred in the clashes between or within gangs. It is alleged that many of the reported incidents involved extrajudicial killings in the course of police's anti-drug operations. ${ }^{16}$ Prosecutor Fatou Bensouda released official statement on October 2016 that the campaign has led to extrajudicial killings causing to the death of nearly 3000 people. ${ }^{17}$ As a response, the Philippines withdraw its membership from the ICC on 17 March 2018. Previously, they had been a state party since August 30,2011, and the statute was entered into force after November 1, 2011. ${ }^{18}$

\footnotetext{
Article 7 (2) (a) Rome Statute 1998.

13 Rodney Dixon in Otto Triffterer, Commentary on the Rome Statute of the International Criminal Court, Nomos Verlagsgesellschaft Baden Baden, 1999, p. 158.

lbid.

ICC, "The Philippines," accessed from https://www.icc-cpi.int/philippines

lbid.

17 ICC, "Statement of the Prosecutor of the International Criminal Court, Fatou Bensouda concerning the situation in the Republic of the Philippines, accessed from https://www.icccpi.int/Pages/item.aspx?name=161013-otp-stat-php

18 ICC, "Background information on situation on the Philippines," accessed from https://www.icccpi.int/Pages/item.aspx?name=pr1371
} 
The previous conflict, which shocking human conscience, is the attack against Rohingya. This conflict develops to be international concern due to discriminative constitution against the Rohingya people resulting them as stateless persons. Forced migration ${ }^{19}$ to Bangladesh, which considered as their origin, is the case that is brought to International Criminal Court by prosecutor Fatou Bensouda. Although Myanmar is not a state party to the ICC, the prosecutor consider that the crime gives impact to Bangladesh, a state party to the ICC. On September 2018, the preliminary examination was launched. It was because of not only the 'deportation' of the Rohingya people from Myanmar to Bangladesh but also other potential crimes under Article 7 of the Rome Statute. The pre-trial chamber agreed that the ICC has jurisdiction over this situation. On July 2019, the prosecutor requested the court to conduct investigation on the crimes of deportation, other inhumane acts, and persecution against Rohingya since October 9, 2016. ${ }^{20}$ Since Myanmar is not a state party to the ICC, they reject the decision of the ICC and argues that the alleged crimes never occurred. ${ }^{21}$

It is important to remember that preliminary examination is not an investigation. Instead, it is a process of examining available information to reach a fully informed determination of a reasonable basis to proceed with an investigation. It should be pursuant to the criteria established by the Rome Statute. ${ }^{22}$ In other words, the ICC will not directly apply its jurisdiction. Rather, it examines whether it has a jurisdiction over a situation. According to the complementarity principle, the ICC put national law as a primary measure. Hence, in this stage, the ICC works with national authorities to ensure the national level performance.

\section{Impunity of Perpetrators}

Most of the perpetrators of serious violation of human rights enjoy impunity and are protected by authorities. One of the reasons is because most of the perpetrators, or the responsible persons, are rulers or high-level state officials who hide behind their immunity or a justification that their act is an order of state. States of Southeast Asia have the similar pattern in terms of crimes under jurisdiction of the ICC. There is always minority group or separation movement is suppressed and treated discriminately by government. Accordingly, most violations are committed by current ruler (either government of armed forces). Despite the

19 Christopher $\mathrm{K}$ Hall in Otto Triffterer, Commentary on the Rome Statute of the International Criminal Court, Nomos Verlagsgesellschaft Baden Baden, 1999, pp. 134-136.

20 ICC, "Preliminary Examination on Bangladesh/Myanmar," accessed from https://www.icc-cpi.int/bangladeshmyanmar

21 Human Rights Watch, Myanmar Events on 2018, accessed from https://www.hrw.org/worldreport/2019/country-chapters/burma

22 Fatou Bensouda, "Statement of the Prosecutor of International Criminal Court Fatou Bensouda, an opening Preliminary Examinations into the situations in the Philippines and Venezuela", accessed from https://www.icc-cpi.int/Pages/item.aspx?name=180208-otp-stat, 
fact that the opposition also commits crimes, government protect the perpetrators, or even law legalizes their action. Therefore, it is understandable that perpetrators freely enjoy their impunity. The situations in the Philippines and Myanmar are clear examples of the issue.

Furthermore, lack of national legislation is also one of the causes of impunity. Several actions of most serious crimes on human rights, international humanitarian law, and international criminal law are not categorized as criminal act. For instance, enforced disappearance in Thailand is not yet defined as criminal act. In fact, Thailand has signed the International Convention for the Protection of All Persons from Enforced Disappearance but has not yet ratified it. ${ }^{23}$ The authority prevents victims from obtaining remedies due to lack of legal basis, as well as incapability or inadequate facility. Hence, the families of disappeared persons have not been able to obtain adequate assistance from the police or other agencies. Consequently, many cases have not been investigated completely. None of the authorities has been responsible for their failure or negligence. The absence of these key laws has provided impunity to the security forces accused of having been involved in serious violation of human rights.

However, existence of national legislation for enforcement of human rights law is not the only guarantee that state will not practice impunity. Various legislations concerning enforcement of human rights law have been enacted in these states. However, it is not always implemented properly. There are many undermined cases, while victims and family never stop demanding government to act properly. In Thailand, legislation gives extensive powers and immunity to the security forces for criminal misconduct and human rights violations. ${ }^{24}$

In the case of past conflict between Indonesia and East Timor, there had been national legislations and trials against perpetrators of serious violation of human rights. Nonetheless, most of them are sentenced below minimum standard as written in law. Furthermore, Indonesia and East Timor have agreed to give amnesty for all perpetrators of human rights violations during Indonesian Military operation in East Timor. ${ }^{25}$

\section{Southeast Asian Countries and The International Criminal Court}

Based on the discussion in the previous section, justice has not been able to reach the victims of serious violations of human rights and humanitarian law in Southeast Asia. Perpetrators of crimes against humanity, war crimes in internal armed conflicts in Myanmar, the Philippines, Thailand, and Indonesia, and allegedly

\footnotetext{
23 Brad Adams, Still no Law on Enforced Disappearance in Thailand, https://www.hrw.org/news/2019/09/01/still-no-law-enforced-disappearance-thailand

24 Human Rights Watch, (no. 36)

25 Ary Hermawan, "Govt Defies Calls for Rights Probe in T. Leste," The Jakarta Post, Jakarta, accessed from8 http://www.thejakartapost.com/news/2009/08/28/govt-defies-calls-rights-probe-t-leste.html
} 
genocide against Karen and Rohingya ethnics in Myanmar are deserved to be prosecuted and punished. The victims should have confidence that justice is done.

Civilians, particularly victims, human rights activists, academicians, and even politicians in Southeast Asia, give various reaction in regards to human rights situations in either their own country or the Southeast Asian region. In each state, civil movements by students and activists, particularly through non-governmental organizations, actively promote human rights in various ways. The aspiration is expressed in demonstration, theatrical performance, rally, public education, publication, even negotiating the ruler or legal measures.

If states disregard people's aspirations for justice, people will struggle to fight for their rights. The International Criminal Court brings a fresh air for justice seeker, including the people of Southeast Asia who look for peace and justice. Although the ICC was initiated by developing countries ${ }^{26}$ and through difficult and long negotiation among states and NGOs, but the Southeast Asian governments react differently. Only two (Cambodia and Philippines) of ten ASEAN member states ratify the Rome Statute 1998. The rest are reluctant or still consider the consequence of being a party to the Statute. Cambodia has become the party to ICC since April 11, 2002. ${ }^{27}$ Thailand signed the statute on October 2, 2002, and the Philippines did it on December 28, 2002 before they both ratified it on August 30, 2011. Subsequently, each country established inter-agency committee as the preparation of the ratification of the Rome Statute 1998. Malaysia and Indonesia are reluctant. However, Indonesia has already put the ratification of the Rome Statute 1998 in their National Action Plan for Human Right and has already established the 2000 Human Rights Court Law. The law has the elements of crimes similar to the Rome Statute although it has only jurisdiction over genocide and crimes against humanity.

Surprisingly, in 2004, the Philippines' state officials believe that the ICC only restricted them, instead of helped them to their combat against the insurgents. ${ }^{28}$ In 2018 President Rodrigo Duterte launched drugs war policy, which found as another practice of extra judicial killings after the previous period of President Arroyo making policy on war on terror.

\section{Ratification of the Rome Statute 1998 of International Criminal Court by the Southeast Asian States}

Based on the international treaty law, a signature may express an acceptance to an agreement. However, the ICC has a different rule. A signature is only preliminary

Romli Atmasasmita, Pengantar Hukum Pidana Internasional, Bandung: Rafika Aditama, 2006, p. 11 http://www.icc-cpi.int/Menus/ASP/states+parties/Asian+States/

28 Toon, V. "International Criminal Court: Reservations of Non-State Parties in South East Asia", Contemporary Southeast Asia, Vol. 26, 2004, p. 220. 
step before a state becomes a party ${ }^{29}$ to the ICC without legal consequences. Therefore, ratification/accession to the Rome Statute 1998 on the establishment of the ICC is a condition that should be fulfilled to exercise the jurisdiction of the ICC. A formal declaration of acceptance may also be taken by state to let the ICC applying its jurisdiction. The legal consequences towards the concerned states will be different to state parties.

A state party to the ICC is bound by two obligations: the implementation of complementarity principle; and the obligation to cooperate. In regards to the principle of complementarity, the ICC will not intervene judicial process of a case unless state is determined unwilling or unable to process the case. ${ }^{30}$ In other words, state has responsibility to prosecute and try any accused perpetrators of crimes under jurisdiction of the ICC. Correspondingly, state should have adequate support according to international law standards, which accommodate its national criminal justice towards crimes under jurisdiction of the ICC. Secondly, state parties are obliged to cooperate fully with the ICC in exercising its jurisdiction. This includes giving immunity towards the ICC personnel when exercising its duty, providing necessary documents, collecting evidences, seizure of accused asset, and all necessary actions. ${ }^{31}$ Not only during investigation and during trial, cooperation is also important in the enforcement after trial. The cooperation among states should also be taken particularly when a case involving other states where extradition and other mutual legal assistance are needed.

Certainly, although there are only two obligations, some other points should be taken into consideration in the implementation of the Rome Statute 1998 by Southeast Asian States. There are indeed differences among the Southeast Asian Nations concerning the ICC. Hence, opportunities and challenges towards the implementation of the 1998 Rome Statute is discussed below.

\section{Opportunities}

Implementation of the 1998 Rome Statute to exercise jurisdiction of the ICC is supported by general principles of international law such as universal jurisdiction, aut dedere aut judicare ${ }^{32}$ (duty to prosecute and to try) and aut dedere aut punere (duty to punish and to extradite). They are opportunities to apply ICC. In addition, under obligation erga omnes, state as a part of international community has a duty

29 See Anthony Aust, Modern Treaty Law and Practice (2 ${ }^{\text {nd }}$ ed), Cambridge University Press, Cambridge, 2007, p. 96, Ian Sinclair, The Vienna Convention on the Law of Treaties ( $2^{\text {nd }}$ ed), Manchester University Press, Manchester, 1984, pp. 39-40.

30 William Schabas, An Introduction to the International Criminal Court, Cambridge: Cambridge University Press, 2001, p. 14

31 Article 99 of the 1998 Rome Statute

32 See Claire Mitchell, Aut Dedere Aut Judicare: The Extradite or Prosecute Clause in International Law, Geneva: Graduate Institute Publication, 2011. 
to apply its jurisdiction over crimes such as international crimes. ${ }^{33}$ This should be applied by the Southeast Asian states.

\section{a. Supporting Related Legal Instruments}

Yet, actual preparation in national legislation will be more adequate as strength to support implementation of the 1998 Rome Statute. Most of the states are already had national legislations related to crimes under jurisdiction of the ICC and other human rights and humanitarian law instruments.

Indonesia has several national legislations that comply with the Rome Statute 1998. The Law Number 39 of 1999 on Human Rights, the Law Number 26 of 2000 on Human Rights Court, the Penal Code, and the Criminal Procedural Code provide adequate legal support to implement the Rome Statute. The Law of Human Rights Court regulates that Indonesian Human Rights Court has jurisdiction over crimes of genocide and crimes against humanity with the elements of crimes similar to the elements of crimes stipulated by the Rome Statute. However, the law does not include war crimes into human rights court jurisdiction although allegation of violation possibly occurs during internal armed conflict between Indonesian Armed Force and some separatist groups. ${ }^{34}$

The Philippines does not have specific national legislations on human rights and human rights court. Hence, its national legislations ${ }^{35}$ concerning the enforcement of basic standards of human rights and criminal law are sufficient.

Myanmar, since 2011, has reviewed their laws. Currently, Myanmar has amended, repealed, and enacted 171 laws in accordance with the Constitution and international human rights conventions to which Myanmar is a state party. ${ }^{36}$ Myanmar has formed an 18-member Human Rights Committee in 2000 with the Minister for Home Affairs as the Chairperson. In 2007, the committee was reconstituted with a 21-member body to enhance its function. Based on the positive political developments, the Myanmar National Human Rights Commission (MNHRC) was established by the Presidential Order on September 2011. It comprises of 15 members from various professional background and ethnics. In

33 Maurizio Ragazzi, The Concept of International Erga Omnes, Oxford University Press, Oxford, 2000, p. 34, see also Andre de Hoogh, Obligations Erga Omnes and International Crimes, Kluwer Law International, The Hague/Boston/London, 1996.

34 Indonesia experienced internal armed conflict with separatist movements Aceh Liberation Movement (Gerakan Aceh Merdeka/GAM), Fretilin (formerly Indonesian Province East Timor), Gerakan Papua Merdeka (Papua Liberation Movement), and South Mollucas Republic (Republik Maluku Selatan).

35 Philippines' national legislations related to the implementation of Rome Statute such as Bill of Rights (1987 Philippines Constitution Article III), Anti Violence Act (Republic Act No. 9262/2004); Board of Claims for victims of unjust imprisonment or detention and victims of violent crimes (Republic Act No. 7309/1992); Penal Code (Act. No. 3815/1930 amended by Republic Act No. 4363/1965); Protection Against child abuse, exploitation and discrimination (Republic Act No. 7610/1992); Rights of Persons Arrested, Detained or under Custodial Investigation (Republic Act No. 7438/1992); Speedy Trial Act (Republic Act No. 8493/1998); Witness Protection, Security and Benefit Act (Republic Act No. 6981/1991) and Anti Torture Act.

36 UNGA, National report submitted in accordance with paragraph 5 of the annex to Human Rights Council resolution $16 / 21$ Myanmar, https://documents-ddsny.un.org/doc/UNDOC/GEN/G15/172/10/PDF/G1517210.pdf?OpenElement, retrieved on 15 August 2018, p. 3 
accordance with the law, the MNHRC was reconstituted with 11 members on September 24, 2014. Currently, it performs its mandates independently and effectively for the promotion and protection of human rights. ${ }^{37}$

\section{b. Strong Motivation by The Community Particularly Victims and Human Right Defenders}

Human rights activists in Indonesia, Malaysia, Philippines, Thailand, and Myanmar actively campaign the ratification of the Rome Statute 1998. Undeniably, the ICC brings good news for victims of serious violations of human rights in Southeast Asia. Since the states apply impunity to the perpetrators of serious crimes of human rights, the ICC is expected to be a trigger for the governments to take serious action and bring justice for all.

The issue of ICC has developed international cooperation among different institutions. Non-governmental organizations, academicians, and other independent body involve in taking study and research to give input to governments for the purpose of the ratification of the Rome Statute 1998. It also involves transnational cooperation with one objective to achieve global justice.

\section{Challenges}

Challenges against the implementation of the 1998 Rome Statute cannot be avoided. This may arise from the skeptics of governments or due to the factual matters in regards to the feasibility of the implementation of the 1998 Rome Statute to national criminal justice system.

\section{a. Defensive and Repressive Authority}

Unstable political situation in developing countries influences criminal justice. The governments of Myanmar, Philippines, Malaysia, and Thailand tend to maximize its power to control all sectors, including law and judicial. In the globalization and democratization era, many states turn their policy to be more 'civilized' and democratic.

Transitional phase from repressive to democratic authority is often become main reason of legal reform. Despite recognizing the principle of rules of law, intervention of legislative or executive authority to judicial body is the common cause of the miserable law enforcement in developing countries. The case of Malaysia and Indonesia is the trouble of eliminating the immunity over state officials or monarchs. In fact, the law stipulates that everyone is equal before law. Another example is in the Philippines. The National Prosecution Service (NPS), who are responsible to prosecute cases in courts, are under the direct control and the supervision of the Department of Justice (DoJ). ${ }^{38}$

Ibid., p. 4

38 Asian Human Rights Commission, "The State of Human Rights in the Philippines 2008: The Human Cost of Insecurity" AHRC-SPR-015-2008 http://material.ahrchk.net/hrreport/2008/AHRC-SPR-015-2008Philippines_AHRR2008.pdf accessed on August 2009, p. 11. 
Another case is the unwillingness of state to change its governmental policy. This is the case of Myanmar that is ruled by military and rejects the idea of democracy. Abuse of power is a tendency committed. Military dictatorship in Myanmar suffers its people. Myanmar is a member of ASEAN, which "aims to promote regional peace and stability through abiding respect for justice and the rule of law in the relationship among countries in the region and adherence to the principle of the United Nations Charter". ${ }^{39}$ However, for the sake of state sovereignty and principle of non-intervention, other ASEAN states are hesitate to "remind" Myanmar. Moreover, Myanmar is reluctant to receive suggestion even from the United Nations. ${ }^{40}$ Nevertheless, Bangladesh challenges Myanmar by reporting the case to the ICC for the crime of deportation, other inhumane acts, and persecution under Article 7 of the Rome Statute. Currently, the case is in ongoing process in ICC.

However, other ASEAN members probably are not as hard as Myanmar in responding to the ICC. Indonesia, Malaysia, and Thailand tend to give diplomatic answer when there is a question regarding the willingness to ratify the Rome Statute. These states' officials argue that ratifying the 1998 Rome Statute is not an emerging issue. Indonesia argues that it has a permanent human rights court as well as necessary related legislations. Therefore, government agrees that the ICC has no function to Indonesia. In addition, these states also view that they consider the ratification by 'wait and see policy'. They would see the actual impact of the implementation of the 1998 Rome Statute in other states, particularly in developed countries to take the lesson and consideration whether it is necessary to be the party to the ICC. ${ }^{41}$

\section{b. Issue of Sovereignty}

The tense between international jurisdictions of the ICC and Southeast Asian states in its national jurisdiction particularly lies on state sovereignty. Some states oppose the referral by the Security Council and propio motu of the prosecutor due to the state sovereignty issue. With the same argument as the United States in opposing the ICC, Southeast Asian states, such as Indonesia and Malaysia also consider the ICC as a threat to state sovereignty.

Security Council may refer a situation in any state to the ICC under Chapter VII of the United Nations Charter although the state is not party to ICC. In other words,

39 Objectives of ASEAN, http://www.aseansec.org/64.htm

40 ASEAN member states have tried to open diplomatic approach to handle the violence against civilians that involve two monks who held peaceful demonstration by marching along Rangoon to negotiate with the junta due to the repression of junta in 2007. Many civilians and monks killed, arbitrarily arrested, and tortured by the junta. The military junta of Myanmar rejected with the argument that it was an internal security matter and no alien should intervene. The government, including Aung San Su Kyi, a noble prizewinner commenting the event of Rohingya in 2017 when Myanmar received international attention including UN Security Council, gave the same argument.

41 Toon, V., op.cit., p. 227. 
there is a possibility that the Security Council refers a situation in a Southeast Asian state.

However, the problem of state sovereignty should have been answered by the complementarity principle of the ICC. As explained previously, the ICC is only able to exercise its jurisdiction if a state meets the condition of genuinely unable or unwilling, which is related to the basic standard of fair trial. Southeast Asian states should not be felt threatened when they can meet the basic standard of fair trial. Indonesia already has the almost complete national legislations including the human rights court. ${ }^{42}$ The key to avoid the ICC's intervention or other international tribunal is to make national court more effective and efficient by adhering international law standard of fair trial.

\section{c. Technical and Financial Matters}

Another challenge is the technical and financial matter of the ICC. The technical procedural standard of the ICC for criminal procedural is quite expensive for Southeast Asian states. State should provide facilities of victims and witnesses protection, court, prison, which comply with international human rights standard. In fact, the facilities and infrastructure of criminal justice system in Southeast Asia are not that convenience. International community can see Indonesian ad hoc tribunal for East Timor that is criticized for the lack of standards of infrastructure and facilities. The judges also criticized compared to the ICTY or the ICTR in Den Haag.

The establishment of a tribunal to be similar to the ICTY and the ICTR is certainly need high cost. In fact, the states prefer to spend their budget to more crucial social needs of their people such as education, health, or economic growth. In addition, there should be special budget and time to prepare tribunal. Consequently, a case can be delayed and, presumably, state is considered unwilling due to unjustified delay. Then, it is unfair for ordinary tribunals when state establishes a special human rights tribunal with its high standard facilities while the other tribunal just having the 'conventional traditional' court. Apparently, it is better to maximize the existing court instead of leaving the perpetrators unpunished without trial or handing cases to the international tribunal intervene. On the other hand, they may be triggers for state to manage their judicial system, infrastructure, and facilities to be better.

\section{d. Inadequate Supported National Legislations}

Some states already have adequate supported national legislations. Unfortunately, some other states still have inadequate national legislation in conform to the ICC.

42 Indeed, Indonesia has Human Rights Court Act as the substantial code. However, it still uses the rules of procedure of ordinary criminal procedure, which is inadequate. However, Indonesian scholars and criminal law experts have been trying to draft the amendment of Criminal Code as well as Criminal Procedural Code, which can accommodate the rules of procedure for serious violation of human rights cases. 
For example, Thailand has no legislation covering enforced disappearance while the act is considered as part of crimes against humanity.

\section{E. Possible Impact in Ratifying Rome Statute 1998}

Indonesia, Malaysia, and Laos have not signed the statute yet but their participation on preparatory commission meetings as well as other related meetings is expected to bring positive impact to their acceptance to the ICC. ${ }^{43}$

\section{As an Instrument of Legal Reform}

The Rome Statute on the establishment of the ICC can be used as a tool of law reform in national legislations. This strategy has been used by Nepal and India. ${ }^{44}$ Through the international human rights standards approach set by the ICC, Nepal changed its regulation on recruitment of child soldier into illegal action. India considered to adapt the 1998 Rome Statute to point some definitions of certain crimes, rules regarding victims, as well as concept of command responsibility. ${ }^{45}$

\section{To Make National Criminal Justice System Effective}

To conform to the principle of complementarity, the ICC can be a catalysator to develop national legal system, particularly in criminal justice, as well as national court. It may have a role, not only in developing national legislations, also in capacity building of legal officers, particularly to prosecute perpetrators of the most serious violations of human rights.

\section{Preference to Participate Actively in all ICC Meetings}

When a state becomes a party to the ICC, it automatically has a right to participate actively instead of being observer. Accordingly, state can give input and opinion either for the related issues to the convention or the implementation of the ICC, including administrative matters. ${ }^{46}$ In addition, it is not impossible for state to give inputs to the ICC for the purpose of exercising its obligation to protect its nationals who is subjected to the ICC jurisdiction.

Other than that, the opportunity to be a part of ICC organs such as judges, prosecutors, or registry is open wide. Only state party to the ICC may propose a name to be in the organs. Consequently, this may bring positive impact to state since it can strengthen its bargain position in international community, particularly in the enforcement of human rights and universal justice.

43 Toon, V. Op.cit., p. 227.

44 International Bar Association, 'Beyond the Hague: Forging Linkages between the International Criminal Court and Key Jurisdictions' (Report) (September 2008), p. 33.

45 International Bar Association, ibid., p.34.

46 Schabas, W., An Introduction to the International Criminal Court, Cambridge: Cambridge University Press, 2001. 


\section{As a Motivation to Improve Human Rights Enforcement}

The ICC can also cause a state to improve its role in the enforcement of human rights for both its nation and the international community. State party to ICC can express its commitment on human rights enforcement through effective tribunal in line with the international criminal law standard.

The ICC should bring positive impact in the development and the enforcement of human rights, as well as humanitarian and international criminal law. It is hardly to find negative impacts of ratifying the 1998 Rome Statute, unless for unprepared states. The ratification of the ICC may make a state to be very busy to prepare national implementing legislations, facilities and infrastructure, capacity building of judicial officials, etc., to comply with the standards of the ICC. Consequently, there might be additional budget and probably total reformation of judicial system, especially in criminal justice system. This may prompt various reactions, including negative critics, to state, particularly concerning financial support as the very sensitive issue anywhere. Strong critics may arise from supporters of economic, social, and cultural rights as well as third generation of human rights. In fact, the debate may arise on the matter when people believe that fulfilling people daily needs is more important than spending huge amount of money to prosecute a war criminal.

\section{F. Effective implementation of the 1998 Rome Statute of the International Criminal Court}

The Southeast Asian states feel anxiety of implementation of the Rome, but they also concern on the preparedness. There are several points that can be taken as follows.

\section{Dissemination and Public Education}

Since there is still misunderstanding of the jurisdiction of the ICC, as well as the principles following it, dissemination and public education on the Rome Statute 1998 should be taken as the first strategy. Dissemination should be subjected to all element of society particularly who concern about the enforcement of human right. However, the most important parties are government, judicial officers (judge, prosecutor, lawyers, and all related officers), armed forces, practitioners, and academicians. Government plays a very important role, as government is the institution that has authority to make laws, policies, and to provide all necessary facilities to ensure that everything is suitable.

\section{Training for Officials to Understand the 1998 Rome Statute of The International Criminal Court}

In implementation stage, a comprehensive understanding towards the 1998 Rome Statute is crucial for practitioners. In addition to knowledge of human rights, it is important to have deep understanding of the ICC. Hence, training or workshop and 
other kind of education for judicial officers as well as armed forces and police should be mandatory.

Since each Southeast Asian country applying different legal system (either common law or civil law), training should provide understanding of other legal system accommodated by the Rome Statute. Furthermore, understanding of international law, criminal law, human rights law, humanitarian law, as well as international criminal law should be understood both theoretically and practically. Hence, the training should not only on theoretical basis but it should also provide simulation.

It is not easy to disseminate and to educate military officers with the human rights and humanitarian law as they argue that it just hinders their function. They argue that human rights and humanitarian law is unnecessary because it is not applied to the belligerent/insurgents. Belligerent often neglects the law of war. Therefore, dissemination of human rights and humanitarian law should be able to reach all community.

\section{Synchronization of Legal Instruments}

Synchronization of national legislations towards international instruments is an important phase that should be taken before the ratification process. It is to examine whether an instrument (the 1998 Rome Statute) is in line with the national legislations. There will be a "uniform interpretation" regarding the international law that will be applied. ${ }^{47}$

Synchronization can be conducted through comparing related international instruments with existing national legislations or even to the bills. Furthermore, synchronization may consider vertically and horizontally. Vertical synchronization compares universal human rights norms and values with local norms. Horizontal synchronization compares all laws in the same level. The result can be law finding, introduce precedent and development of international criminal law and humanitarian law such as new principles (individual criminal responsibility, commander, and superior responsibility) and definition of crimes (element of crimes, war crimes, international and non-international armed conflict, crimes against humanity, principles in sentencing) to be in line with the principles of international law.

The ratification of the 1998 Rome Statute of the ICC requires national legislation to have adequate implementation of the ICC, especially in regards to international criminal law and humanitarian law. The most important consideration is that national legislation should be able to comply with the obligations regulated by the Rome Statute such as cooperation and enforcement. In addition, national

47 Lattanzi. F., "The International Criminal Court and National Jurisdiction" in Politi, M., and Giuseppe Nesi (eds), The Rome Statute of the International criminal Court: A Challenge to Impunity, England: Ashgate, 2002, p. 194. 
legislation should be in accordance with the 1998 Rome Statute to comply with the implementation of complementarity principle.

\section{Transparent Draft and Implementation of Legislations}

After synchronization, the next step is to draft and implement legislations of the Rome Statute, which are in line with national legislations of state. Certainly, all process should be done transparently. Therefore, public can participate either actively or passively. The implementation of the new law will not become an empty case of written law or a threat to the people.

\section{G. Conclusion}

Some states do not have sufficient national legislations in regards to the protection of human rights that are able to accommodate the most serious crimes of international criminal law, including its enforcement. Hence, it is understandable that many perpetrators enjoy impunity. Therefore, the ICC can play its role as a trigger of the development of criminal justice enforcement at the national level. At the same time, the ICC also can take measured actions to end impunity and bring justice for the victims.

The existing national legal instruments related to ICC can support the implementation of the Rome Statute 1998 in Southeast Asia and achieve the objectives of the ICC to end impunity and achieve global justice. However, some governments of Southeast Asian states have less willingness to bring justice based on the argument of undeniable state sovereignty. Based on the principle of complementarity, the ICC is proposed to strengthen national criminal justice of a state. The government should ensure the enactment of national legislations concerning serious violations of human rights and international humanitarian law, particularly under the jurisdiction of the ICC. State must guarantee an independent mechanism to investigate and to try serious violations of human rights and international humanitarian law. Therefore, the ICC should not be considered as a threat to national sovereignty of a state.

\section{References}

\section{Books}

Aust, Anthony, Modern Treaty Law and Practice $\left(2^{\text {nd }}\right.$ ed), Cambridge University Press, Cambridge, 2007.

de Hoogh, Andre, Obligations Erga Omnes and International Crimes, Kluwer Law International, The Hague/Boston/London, 1996.

Dixon, Rodney in Otto Triffterer, Commentary on the Rome Statute of the International Criminal Court, Nomos Verlagsgesellschaft Baden Baden, 1999.

Graham, Hugh Davis, The Civil Rights Era: Origins and Development of National Policy, 1960-1972, Oxford, 1990. 
Hall, Christopher $\mathrm{K}$ in Otto Triffterer, Commentary on the Rome Statute of the International Criminal Court, Nomos Verlagsgesellschaft Baden Baden, 1999.

Mitchell, Claire, Aut Dedere Aut Judicare: The Extradite or Prosecute Clause in International Law, Graduate Institute Publication, Geneva, 2011.

Morris, Madeline, "Complementarity and its Discontents: States, Victims, and The International Criminal Court" in Dinah Shelton (ed), International Criminal Crimes, Peace and Human Rights, Transnational Publisher, Ardsley, New York, 2000.

Lattanzi. F., "The International Criminal Court and National Jurisdiction" in Politi, M., and Giuseppe Nesi (eds), The Rome Statute of the International criminal Court: A Challenge to Impunity, Ashgate, England, 2002.

Ragazzi, Maurizio, The Concept of International Erga Omnes, Oxford University Press, Oxford, 2000.

Romli Atmasasmita, Pengantar Hukum Pidana Internasional, Rafika Aditama, Bandung, 2006.

Schabas, W., An Introduction to the International Criminal Court, Cambridge University Press, Cambridge, 2001.

Sinclair, lan, The Vienna Convention on the Law of Treaties ( $2^{\text {nd }}$ ed), Manchester University Press, Manchester, 1984

\section{Other Documents}

Adams, Brad, "Still no Law on Enforced Disappearance in Thailand," https://www.hrw.org/news/2019/09/01/still-no-law-enforced-disappearancethailand

Ary Hermawan, 'Govt Defies Calls for Rights Probe in T. Leste', The Jakarta accessed from http://www.thejakartapost.com/news/2009/08/28/govt-defies-callsrights-probe-t-leste.html

Asian Human Rights Commission, 'The State Of Human Rights In The Philippines 2008 : The Human Cost Of Insecurity' AHRC-SPR-015-2008, accessed from http://material.ahrchk.net/hrreport/2008/AHRC-SPR-015-2008-

Philippines_AHRR2008.pdf accessed August 2009

ASEAN, Objectives of ASEAN, accessed from http://www.aseansec.org/64.htm

Bensouda, Fatou, "Statement of the Prosecutor of International Criminal Court Fatou Bensouda, an opening Preliminary Examinations into the situations in the Philippines and Venezuela," https://www.icccpi.int/Pages/item.aspx?name=180208-otp-stat,

Gegout, Catherine, "The International Criminal Court: Limits, Potentials and Conditions for the Promotion of Peace and Justice", Third World Quarterly, Vol. 34 Issue 5, 2013.

Human Rights Watch, Myanmar Events on 2018, accessed from https://www.hrw.org/world-report/2019/country-chapters/burma 
ICC, "Background information on situation on the Philippines," accessed from https://www.icc-cpi.int/Pages/item.aspx?name=pr1371

ICC, Preliminary Examination on Bangladesh/Myanmar, accessed from https://www.icc-cpi.int/bangladesh-myanmar

ICC, "The Philippines," accessed from https://www.icc-cpi.int/philippines

ICC, "Statement of the Prosecutor of the International Criminal Court, Fatou Bensouda concerning the situation in the Republic of the Philippines, accessed from https://www.icc-cpi.int/Pages/item.aspx?name=161013-otp-stat-php

ICC Press Release, Press Release: 20 March 2018, ICC Statement on The Philippines' notice of withdrawal: State participation in Rome Statute system essential to international rule of law, accessed from https://www.icccpi.int/Pages/item.aspx?name=pr1371 on 15 August 2018.

International Bar Association, 'Beyond the Hague: Forging Linkages Between the International Criminal Court and Key Jurisdictions', Report of September 2008.

Morris, Adlon D, "A Retrospective on the Civil Rights Movement: Political and Intellectual Landmark", Annual Review of Sociology, Vol.25, 1999.

Ocampo Louis Moreno, "The International Criminal Court: Seeking Global Justice", Case Western Journal of International Law, Vol. 40, Issue 1, 2008.

Toon, V. "International Criminal Court: Resercations of Non-State Parties in Southeast Asia", Contemporary Southeast Asia, Vol. 26, 2004.

UNGA, National report submitted in accordance with paragraph 5 of the annex to Human Rights Council Resolution 16/21 Myanmar, accessed from https://documents-dds-

ny.un.org/doc/UNDOC/GEN/G15/172/10/PDF/G1517210.pdf?OpenElement

\section{Law Document}

The Law Number 39 of 1999 on Indonesian Human Rights

The Law Number 26 of 2000 on Indonesian Human Rights Court

Indonesian Penal Code

Indonesian Criminal Procedural Code

The 1987 Constitution of the Philippines

The Philippines' Republic Act Number 9262 of 2004 on the Anti-Violence against Women and Their Children Act

The Philippines' Republic Act Number 7309 of 1992on the Act Creating a Board of Claims under the Department of Justice

The Philippines' Republic Act Number 3815 of 1930on the Philippines Penal Code, which is amended by The Philippines' Republic Act Number 4363 of 1965);

The Philippines' Republic Act Number 7610 of 1992 on Providing for Stronger Deterrence and Special Protection against Child Abuse, Exploitation, and Discrimination, Providing Penalties for Its Violation and for Other Purposes

The Philippines' Republic Act Number 7438 of 1992 on An Act Defining Certain Rights of Persons Arrested, Detained or Under Custodial Investigation as well as 
the Duties of the Arresting, Detaining, and Investigating Officers and Providing Penalties for Violations Thereof

The Philippines' Republic Act Number 8493 of 1998 on An Act to Ensure A Speedy

Trial Of All Criminal Cases Before The Sandiganbayan, Regional Trial Court, Metropolitan Trial Court, Municipal Trial Court, And Municipal Circuit Trial Court, Appropriating Funds Therefor, And For Other Purposes

The Philippines' Republic Act Number 6981 of 1991 on Witness Protection, Security and Benefit Act

$\begin{array}{llll}\text { Prosecutor } & v & \text { Ratco } & \text { Mladić }\end{array}$

http://www.icty.org/x/cases/mladic/ind/en/mla-ai021010e.pdf

Prosecutor v Karadžić (IT-95-5/18-I)

Rome Statute 1998

Sudan the Prosecutor v Omar Hassan Ahmad Al Bashir case no. ICC-02/05-01/09. 